\title{
CONSUMER AWARENESS AND USAGE OF ISLAMIC BANKING Products in South Africa
}

\author{
Yvonne Saini, Geoff Bick and Loonat Abdulla
}

Wits Business School, University of the Witwatersrand

Accepted June 2011

\begin{abstract}
This paper investigates the level of consumer awareness and use of Islamic banking products in South Africa. A non-probability sampling method was used whereby a questionnaire was administered to 250 respondents and statistically analysed to determine the factors that are important in the choice between Islamic or conventional banks. It was found that Muslims are aware of Islamic banks, but their rate of use is low, as Muslim customers regard efficiency, lower bank charges, the availability of automatic teller machines and an extensive branch network as important factors when it comes to choosing a bank, rather than religious motivations for compliance with Islamic conventions. It was concluded that, if Islamic banks wanted to attract and retain customers and remain relevant in the South African context, they would have to develop relevant strategies designed to meet customers' needs. Religion as the sole motivation for choosing Islamic banks is inadequate.
\end{abstract}

Key words: banking, Islam, consumer awareness, consumer usage

JEL: G21, L84

1

\section{Introduction}

The value of the Islamic banking and finance market was estimated to be between US\$200 billion to US\$500 billion worldwide in 2006 (Ibrahim \& Seoweng, 2006). Islamic banking is growing at an average rate of 15 per cent a year, which makes it the fastest-growing sector in the financial markets of the contemporary world (Saidi, 2007; Chong \& Liu, 2008). According to banking statistics, the growth rate of Islamic banking has outpaced traditional banking during the past decade (Ghannadian \& Goswam, 2004). Islamic banks have grown in size and number around the world and are generally the product of private initiatives (Aggarwal \& Yof, 2000).

Researchers are seeking to assess both the extent to which customers use Islamic banking products and services (Naser \& Al-Khatib, 1999) and the behaviour, attitudes and perceptions of the target markets (Metawa, 1998). This paper attempts to estimate consumer awareness and use of Islamic banking products in South Africa. If Islamic banks are to achieve their mission and objectives, they will have to understand their customers' perceptions (Metawa, 1998; Dusuki \& Abdullah, 2007). Despite the popular claim that Islamic banks are true reflections of Muslim lifestyles and practices, and that clients respect and believe in their principles, studies indicate that religious motivation is not the sole criterion for the selection of Islamic banking institutions or services (Dusuki \& Abdullah, 2007). Studies have identified other factors, such as costs, benefits, service delivery (fast and efficient), the size and reputation of the bank, convenience (location and ample parking) and the friendliness of bank personnel as important criteria for selecting particular Islamic banks (Dusuki \& Abdullah, 2007). If Islamic banking is to be accepted and used by the target market, the banks will have to understand their customers and make their services and products easily available.

It is estimated that there are currently about 1 million Muslims in South Africa, while in 1970 there were only about 270,000 (History of Muslims in South Africa, 2007). Muslims of Malay origin are found mainly in the Western 
Cape, while those of Indian origin are resident mainly in Kwazulu-Natal, Gauteng and Mpumalanga. Formalised Islamic banking, finance and investment products in South Africa are in their infancy, having been established in 1989. Islamic banks that offer products according to Shariah law include the Albaraka Bank and Oasis Asset Management. Wesbank has established an Islamic subsidiary known as the Islamic Finance Bank, while ABSA and the FNB have opened Islamic banking departments. The fully-fledged Islamic banks operating in South Africa are Albaraka, HBZ and the Habib Bank (Saidi, 2007).

The Albaraka Bank pioneered Islamic banking and finance in South Africa in 1989 in response to the need for a system of banking in line with Islamic economic principles. Albaraka offers only Shariahcompliant products and services. The head office is situated in Durban, with branches in Durban, Cape Town, Johannesburg and Pretoria. Albaraka Bank offers investment and financing products, and, at the time of the study, did not offer any transactional products and services. Products and services offered to Muslims and non-Muslims include residential property, motor vehicle, trade, savings, investment accounts, equity participation accounts, equity share portfolio funds and estate planning finance.

In addition to Islamic banking institutions in South Africa, Oasis Crescent Capital was established in 2002 and offers Shariahcompliant equity funds. The Oasis group offers conventional equity funds and unit trusts. In 2004, WesBank, in partnership with Pure Capital, began offering a Shariah-compliant vehicle finance product in response to consumers wishing to finance vehicles in a manner which is compliant with Shariah Law. The Habib Overseas Bank and Habib Bank Zurich have local branches in South Africa. Islamic banking in South Africa was tainted by the downfall of the Islamic Bank Ltd, which was liquidated in 1997. Total deposits and assets at the time of liquidation were estimated to be worth about R150 million and R190 million respectively.

In order to understand Islamic banking practices and target markets, this study focused on South Africa, which has a fully-fledged conventional banking sector and the presence of Islamic banks. South Africa has a sophisticated, well-developed banking industry (Saunders, Bendixen \& Abratt, 2007). There are about 33 South African banks and 14 foreign banks, with the largest five banks holding 83 per cent of the total assets. In 2006 there were about 30.2 million accounts (Saunders et al., 2007). In recent years, there has been increased competition from new entrants into the banking industry (Saunders et al., 2007), and Islamic banking is posing a serious challenge (Saidi, 2007).

There are gaps in the understanding of customers' needs when it comes to the provision of adequate services and products (Funfgeld \& Wang, 2009). In countries like Indonesia, consumers have been waiting for proper Shariah banking facilities, and some keep their money in drawers and closets, under the bed or even in the care of a local Islamic teacher, as they think that the conventional banks will use the money improperly (McCawley, 2004). Little is known about the use of Islamic banking in South Africa. The remaining text of this paper is organised as follows: section 2 is a review of the relevant literature, and section 3 describes the methodology employed. Section 4 presents the analysis and discussion of the findings. Finally, section 5 provides conclusions and recommendations.

\section{2}

\section{Literature review}

It is estimated that there are about 1.8 billion Muslims in the world and, after Christianity, Islam is the next largest religion. Islam is the predominant religion in the Middle East and parts of Asia, Africa and in countries such as Turkey, Iran, Iraq, Egypt, Nigeria, Indonesia, India, Pakistan and Bangladesh. In Iran, Pakistan and Sudan, only Islamic banking is allowed (Chong \& Liu, 2008). Apart from these areas, there are migrant Muslims all over the world, including South Africa and the United States of America. Owing to the presence of Muslims, international banks such as Citibank have created wings to cater for Muslim clients, offering diverse products, mainly financing businesses (Citibank, 2009). 
In the USA, Devon Bank offers Islamic financing services which are Shariahcompliant, and provides construction and home loan financing following Murabuha guidance (Devon Bank, 2009).

Islamic banks have enjoyed phenomenal growth, from an asset base of barely US\$ 1 billion in 1975 and fewer than 10 Islamic banks (Martin, 1997). There are more than 180 Islamic banks and financial institutions operating more than 8000 branches in different countries in Asia, Africa, the Middle East, Europe and North America. It is expected that by 2010 Islamic Banks and financial institutions will comprise 50 per cent- 60 per cent of the total private savings of Muslims worldwide (Gainor, 1999).

The major determinant for the future of banking is the customers, as their preferences must be the main focus of attention. This is because the customers' mode of living comprises the needs that the banks have to match (Eriksson, 2008). In today's competitive environment, it is imperative that bank managers develop the ability to determine the critical bank selection factors for the segments of the market they wish to attract and serve (Har \& Ta, 2000).

\subsection{Differences between Islamic and conventional banking}

Islamic banking is based on the prohibition of interest, which is founded not on the principles of economics but on religious beliefs (Ghannadian \& Goswami, 2004). The basic principle of Islamic banking is the prohibition of interest or "riba" where banks are not expected to charge interest for lending money to customers, money lending should be interest free. Not charging interest requires the Islamic banks to finance investment projects through profit and loss sharing. According to Islamic banking principles, the prevailing practice of charging interest in the conventional banking system is an injustice to borrowers, as the interest on loans has to be paid irrespective of the outcomes of their business (Dusuki \& Abdullah, 2007). In other words, Islamic banking deals with the creation of equity (through profit and loss sharing schemes) and rental income, whereas the pillar of conventional banking is debt through interest (Patel,
2006). Islamic banking is constructed upon the principle of brotherhood and cooperation, which stands for a system of equity and risksharing (Dusuki \& Abdullah, 2007). Initially, Islamic banks targeted only Muslims, but this has changed, and non-Muslim clients are welcomed. Islamic banking and financing are similar to conventional banking (El-Gamal, 2000). However, Islamic banking strictly prohibits interest, but it does permit profit from a trading activity. The major difference between Islamic banking principles and traditional practices resides in the fact that the banker and the borrower are both at risk in a project. Islamic banking does not espouse profiting that violates religious law in any way or is harmful to the stakeholders inherent in the business or economic activity (Patel, 2006). Islam regards interest financing as immoral, as well as socially and economically harmful, for a number of reasons. The extension of credit increases the money supply, which stimulates demand, but does not always result in real, tangible economic activity. In fact, it often results in a variety of economic ills, such as inflation, continued unemployment and widening income gaps (Patel, 2006). Further, in Islamic banking practice, investment funds are not used in the production of armaments, alcohol and tobacco, in offensive advertising or cruelty to animals (Dusuki \& Abdullah, 2007).

Islamic banking is different from conventional banking because interest (Riba) is prohibited in Islam, seeing that banks are not allowed either to offer a fixed rate of return on deposits or to charge interest on loans (Chong \& Liu, 2008). Shariah law prohibits Riba (interest or usury). The etymology of the term Riba can be traced back to the Arabic verb $R a b a$, the literal meaning of which is 'to increase'. The official definition of Riba, according to the four major Muslim Jurist schools, is "trading two goods of the same kind in different quantities, where the increase is not a proper compensation" (El-Gamal, 1997: 3). Another definition of Riba is "the unjustified earning or receiving of any monetary advantage in a business transaction without giving a just counter value" (AbdelHaq \& Al-Oma, 1996:7). There is consensus among Muslim scholars that this prohibition of 
interest income extends to all forms of interest, and there is no difference between interestbearing funds for the purposes of consumption or investment (Abdel-Haq \& Al-Oma, 1996). Islam permits loans on an interest-free basis for charitable purposes, and trading and investment based on profit-and-loss and risksharing. The main differences between conventional and Islamic banks are highlighted in Table 1.

\section{Table 1}

Differences between Islamic banking and conventional banks

\begin{tabular}{|c|c|}
\hline Conventional banking system & Islamic banking system \\
\hline Charge interest on loans. & $\begin{array}{l}\text { Do not charge interest. Riba (interest) is an unjust return, interest or usury. } \\
\text { The term applies to any financial gain by the lender as a condition of a loan } \\
\text { and in a commodity trade. It also applies to any disparity in quantity or time } \\
\text { of delivery, as such transactions are illegal under Islamic law (Martins, } \\
\text { 1997; Chong \& Liu, 2008). } \\
\text { Zero-return loans. Prohibits the charging or receiving of interest. A unique } \\
\text { feature of Islamic banking is its profit-and-loss sharing (PLS) paradigm, } \\
\text { which is based mainly on the mudarabah (profit-sharing) and Musyaraka } \\
\text { (joint venture) concepts of Islamic contracting (Chong \& Liu, 2008). }\end{array}$ \\
\hline $\begin{array}{l}\text { Principal stakeholders are } \\
\text { shareholders. }\end{array}$ & $\begin{array}{l}\text { The principal stakeholder is God. The aim is to serve God, while the } \\
\text { stakeholders are the clients and the general public. Clients are partners } \\
\text { and the decisions are in the interest of society. }\end{array}$ \\
\hline $\begin{array}{l}\text { Support arms industries and } \\
\text { industries that pollute the } \\
\text { environment and exploit children. }\end{array}$ & $\begin{array}{l}\text { Shariah law places restrictions on business activities. The law further } \\
\text { prohibits trading in alcohol, tobacco, products that contain pork, defence } \\
\text { and weapon production and certain entertainment activities like gambling } \\
\text { and pornography (Chong \& Liu, 2008). }\end{array}$ \\
\hline $\begin{array}{l}\text { Gives loans to whoever has a } \\
\text { guarantor or collateral. }\end{array}$ & Gives loans to those who need loans. Do not need collateral to get a loan. \\
\hline $\begin{array}{l}\text { Decisions are made in the interest of } \\
\text { shareholders. }\end{array}$ & $\begin{array}{l}\text { Islamic principles advocate for an economic system in which all forms of } \\
\text { exploitation are eliminated. The other principle is Mudaraba (trust } \\
\text { financing), a profit-sharing agreement between two parties in which one } \\
\text { provides the finance and the other provides entrepreneurial and } \\
\text { management skills. Profits are divided according to a predetermined ratio. } \\
\text { Losses are borne by the provider of capital. }\end{array}$ \\
\hline $\begin{array}{l}\text { Designed for those who have money } \\
\text { and who do not care what it is used } \\
\text { for. Consumers have no opportunity } \\
\text { to choose where money is invested. } \\
\text { Provides no information about what it } \\
\text { does with depositors' money. }\end{array}$ & $\begin{array}{l}\text { Islamic banks have an interest in how the money borrowed is used. The } \\
\text { Islamic banks have a stake in the financal activities so that money is not } \\
\text { used for economic activities that are injurious to society. } \\
\text { Those who lend to the Islamic banks expect the banks not to invest their } \\
\text { money in business activities that are not Shariah-compliant. } \\
\text { Islamic banks invest only in business activities that are Shariah-compliant. }\end{array}$ \\
\hline $\begin{array}{l}\text { Its investment rewards companies } \\
\text { even if they act irresponsibly. }\end{array}$ & $\begin{array}{l}\text { Islamic banks share profits and losses. Murabaha (cost-plus financing) is a } \\
\text { contract sale between the bank and its client for the sale of goods at a price } \\
\text { that includes a profit margin for both parties. As a financing technique, it } \\
\text { involves the purchase of goods by the bank as requested by its client. }\end{array}$ \\
\hline $\begin{array}{l}\text { Seeks to satisfy demand. } \\
\text { Conventional banks open branches } \\
\text { in those areas that have sufficient } \\
\text { demand but not needs. They open } \\
\text { accounts for individuals whose } \\
\text { income levels can create demand for } \\
\text { banking services and not for those } \\
\text { that might be in need of such } \\
\text { accounts. }\end{array}$ & Seeks to satisfy need \\
\hline
\end{tabular}

Source: adapted from Saidi (2007) and Martin (1997).

While Islam strictly prohibits interest, it strongly encourages profit and loss and risksharing investments. While both trading and interest generate an increase in capital, the increase generated by trading is welcomed, and only the increase generated by interest is prohibited. Shariah does not consider money to be the sort of commodity that sets a price on its use. Instead, it views money as a medium of exchange in an asset-oriented economy and a 
store of value (Abdel-Haq \& Al-Oma, 1996).

Islamic banking also prohibits economic activities that are morally and socially injurious. This prohibition arises from the Islamic principles that advocate for the establishment of an economic system in which all forms of exploitation are eliminated. It is believed that injustice is perpetuated in that the financier is assured of a positive return without doing any work or sharing in the risk, while the entrepreneur, in spite of his management and hard work, is not assured of a positive return. In other words, Islamic banking promotes the establishment of justice between the financier and the entrepreneur (Chapra, 1986; Ali, 1993). The prohibition of interest does not mean that capital is costless. Islam recognises capital as a factor of production rather than a commodity and permits the earning of profit from a trading activity (AlOmar \& Abdel-Haq, 1996). In the profit-andloss sharing paradigm, Islamic banks are required to put in more effort to distinguish good customers from bad ones, because they have more to lose than do conventional banks, as they have to monitor their investments and borrowers closely (Chong \& Liu, 2008).

In Iran and Pakistan, the Islamic banking system has been adopted at the macro level of the economy. Many Muslim countries, such as Bahrain, Dubai, Kuwait, Saudi Arabia and Malaysia, have adopted a dual interest-based and interest-free banking system. In countries where Muslims are a minority, such as the UK, Denmark, the USA, Australia, Singapore and South Africa, some interest-free banks or investment institutions have been established and some interest-based banks have begun offering interest-free banking products.

\subsection{Consumer behaviour in bank decision-making criteria}

Consumer behaviour comprises the activities undertaken when obtaining, consuming and disposing of products and services (Blackwell, Miniard \& Engel, 2006). At the level of marketing theory and practice, the consumer is central to all activity (Hollywood, Armstrong $\&$ Durkin, 2007). The consumer decisionmaking process is the sequence of mental and physical steps taken by consumers from the point of realising that they want a certain product or service to the time when it becomes surplus to their requirements and is disposed of (Vrontis \& Thrassou, 2007). Consumer behaviour and consumer decision-making processes are the results of a combination of consumer environment factors like culture, social context and family, and specific individual factors like personality, values, attitudes, motivation and lifestyle (Vrontis \& Thrassou, 2007). Researchers have identified "significant variables" which influence consumer behaviour, a multitude of decision strategies and a vast reservoir of knowledge about consumer decisions. The consumer decision-making model stipulates that consumers move in stages from need recognition, information search, evaluation of alternatives, purchase and post-purchase evaluation (Hawkins, Best \& Coney, 2004; Blackwell et al., 2006; Schiffman \& Kanuk, 2007). As consumers move through these stages, they experience internal and external influences ranging through culture, social class, personality and motivation.

Empirical research using different methodologies and approaches has been carried out in various parts of the world to examine the criteria for influencing consumers in selecting their bank (Wel \& Nor, 2003; Haron, Ahmed $\&$ Planisek, 1994). The issue of understanding how customers select banks is important, assisting banks in identifying the appropriate marketing strategies needed to attract and retain customers (Almossawi, 2001). One of the major influences on Islamic banking is religion, as consumers want to deal with Shariah-compliant banks. In a study conducted in Jordan, however, it was found that religious motivation was not a primary criterion for selecting Islamic banking services (Dusuki \& Abdullah, 2007).

Consumer decision-making on the choice of a bank is influenced by personal, psychological, external or social factors. Individual decision-making always occurs in a social, cultural, environmental or class context, as human beings interact and need to consider other people's responses (Blythe, 2008). External factors include culture, age, reference by friends, family, social class and subculture, and marketing activities (Hawkins et al., 2004). Social factors include family, social 
groups, reference groups and word-of-mouth communication. Other external factors include the reputation and image of a bank, its prestige, name and social class, and recommendations by relatives and friends (Wel \& Nor, 2003). Social institutions and groups have a powerful influence on consumers in terms of what they purchase and consume (Wel \& Nor, 2003). Internal influences deal with selfconcept and the subsequent lifestyle, based on psychological and physical influences like personality, values, emotions, memory, perception and motives (Hawkins et al., 2004). Personal factors or influences are the consumer's internal inclinations as to whether or not to engage in the relationship with the banks. This includes factors such as convenience, the availability of ATMs and the safety of personal funds (Wel \& Nor, 2003). Banking is a service, so word-of-mouth communication, past experiences and personal needs play an important role in both the choice of a bank and the evaluation of its performance. The service quality model indicates that reliability, responsiveness, assurance, empathy and tangibles are brought into consideration by consumers when assessing the service quality (Kotler \& Keller, 2009). Table 2 below highlights some of the factors that influence consumers in their choice of a bank.

In a study conducted in Bahrain, the youth segment indicated that the five most influential factors for bank selection were in the following order: convenient ATM locations, the availability of ATMs in several locations, bank reputation, 24-hour availability of ATM services, and the availability of nearby parking space (Almossawi, 2001). The least influential factors were: the employer using the same bank, and recommendations by friends and relations. In contrast with the study conducted among students in the UK, recommendation by friends and family was the most important criterion, followed by reputation and the image of the financial institution (Tank \& Tyler, 2005). This shows that in some environments non-commercial sources like word-of-mouth, family and friends have greater influence than the bank's marketing strategies (Tank \& Tyler, 2005).

Table 2

Some factors influencing consumers in the choice of banks

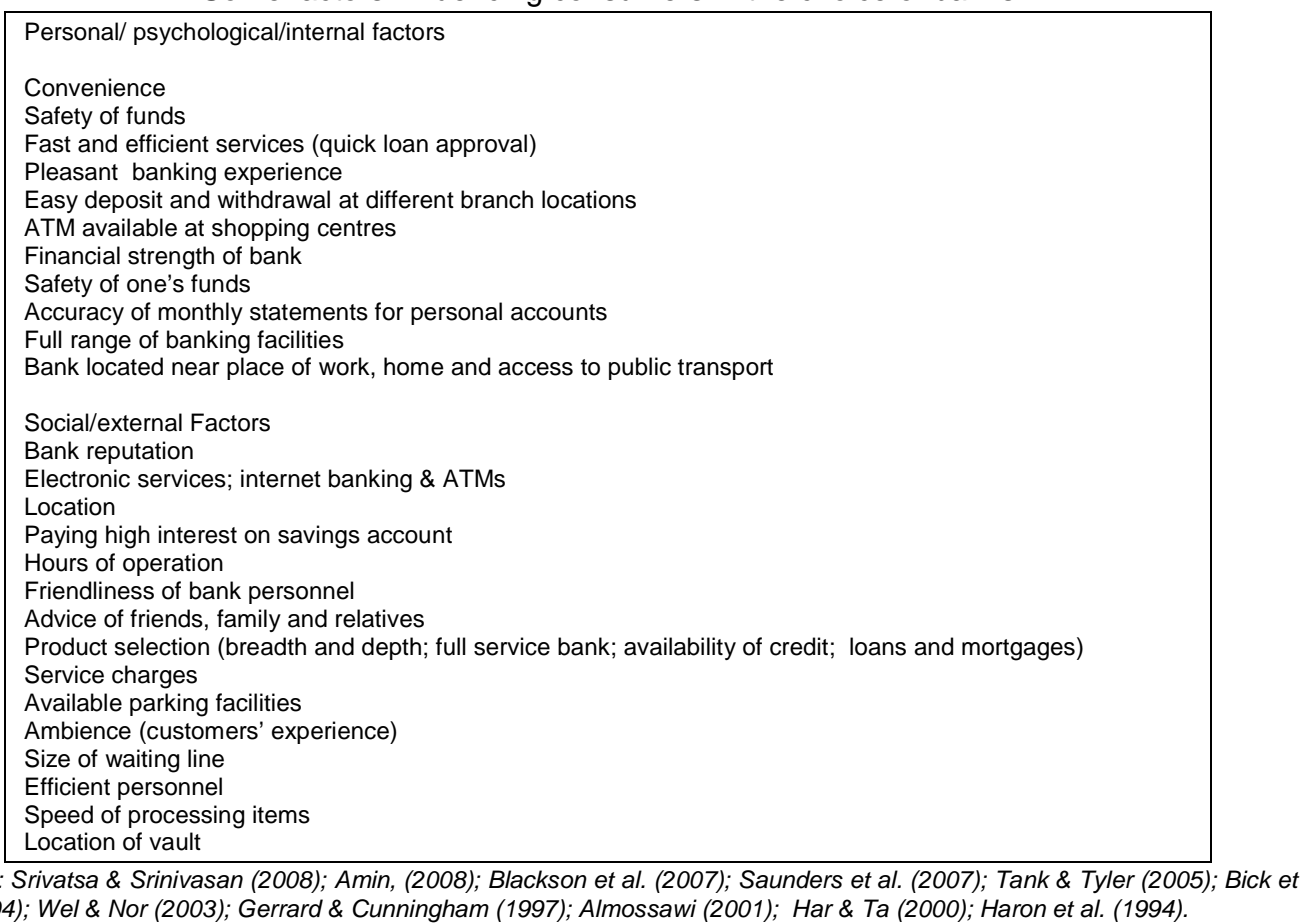

Source: Srivatsa \& Srinivasan (2008); Amin, (2008); Blackson et al. (2007); Saunders et al. (2007); Tank \& Tyler (2005);
al. (2004); Wel \& Nor (2003); Gerrard \& Cunningham (1997); Almossawi (2001); Har \& Ta (2000); Haron et al. (1994). 
Bank customers have diverse needs and display different attitudes towards risk and saving behaviours (Funfgeld \& Wang, 2009). Muslims lack understanding of Islamic banking and its requirements. In Singapore, only 20.7 per cent of those surveyed knew the meaning of riba, 31 per cent knew the meaning of Shariah, and no respondent could explain accurately the meaning of Murabaha, Ijarah and Musharakah (Hamid \& Nordin, 1998).

Literature shows that the main factors influencing the choice of bank are: the pricing structure of services, friends' referrals on banks, switching costs and service quality (Abratt \& Russell, 1999). In a South African study by Abratt and Russell (1999) on the criteria used by consumers in the selection of a private bank, it was found that price was an important criterion, modified by trust, service quality and the availability of the bank.

In a study conducted in Singapore among undergraduate students, the most important factors in their bank selection were feeling secure, a strong desire for a bank to have an available electronic service, and the provision of wider services (Gerrard \& Cunningham, 1997). Convenience was the fourth factor, while social or personal influences were the least important. This is in contrast with findings in a study conducted in the USA, in which convenience was shown to be the most important factor (Blackson et al., 2007).

In another study conducted on the urban informal lower income sector in South Africa, it was found that the important factors in the patronage of banks were the friendliness of bank personnel, location near home, the speed of transaction, fast and efficient service, communication with the bank manager, and low service charges; recommendations by family and friends was rated lowest in the patronage factors (Saunders et al., 2007).

Research conducted among students in the UK revealed that they chose a retail bank mainly owing to recommendations by friends and family; other factors included the reputation or image of the financial institution (Tank \& Tyler, 2005). The results of this study revealed that the bank's Internet websites played an important role in influencing the choice of bank (Tank \& Tyler, 2005).
In a study exploring the determinants of bank selection across the USA, Taiwan and Ghana, the results indicated that, in the USA, convenience was the most important factor, followed by competence, recommendation by peers, and free banking with no bank charges (Blackson et al., 2007). In Taiwan and Ghana, competence was the most important factor; the second factor for the Ghanaians was recommendation by peers, whereas for the Taiwanese it was convenience (Blackson et al., 2007). On the other hand, the provision of fast and efficient services was one of the most important criteria in bank choices (Amin, 2008).

In a study carried out among the new age youth in India, convenience was found to be the most important factor in their bankselection criteria, followed by Internet banking and the availability of ATMs (Srivatsa \& Srinivasan, 2008).

In conclusion, personal and social factors influence the choice of bank. Banks need to know which factors are important when developing strategies that would meet the needs of the customers.

\section{3}

\section{Methodology}

Descriptive research design was used, as it is appropriate for answering questions on who, what, where, when, and how, and it was also desirable because the findings could be inferred to a larger population (Malhotra \& Birks, 2007). This type of research provides information on understanding consumers as well as insights into factors that influence purchase decisions.

\subsection{Population and sample}

The population is the entire group under study (Malhotra \& Birks, 2007), which is about 1 million Muslims residing in South Africa. The sample is a subset of the population that should represent the entire group (Malhotra \& Birks, 2007). For this research, only Muslims aged 18 years and older who had a relationship with a bank were approached. Initially, the researchers had intended to survey both Muslims and non-Muslims, and then to 
compare the data from each group. The questionnaire for the pilot study was adapted from the study by Gerrard and Cunningham (1997), which was conducted amongst Muslims and non-Muslims in Singapore. The questionnaire was pre-tested to create reliability. However, the pilot study indicated that almost all non-Muslims were unaware of Islamic banking, finance and investment products and their applications. The research was then limited to Muslims only.

A non-probability convenience sampling method was used, which could result in bias and a non-representative sample (Galpin, 2000). Personal interviews were conducted using a questionnaire constructed to aid in the collection of data. A total of 1000 questionnaires were distributed and 272 responses were received, of which 250 were complete and sufficient for statistical analysis. Respondents were either contacted in person outside the four main banks in South Africa (Nedbank, the Standard Bank, the First National Bank and ABSA) and Albaraka bank, at major shopping and business centres, and via e-mail. This was done by the field worker, who was one of the researchers.

The measuring instrument was a questionnaire, which was completed by the respondents. The assumption was that the respondents would be competent in reading and understanding English, so they could select answers in the questionnaire.

Demographic data such as age, race, gender, income level, occupation and level of education were collected; nominal, ordinal, interval and ratio scaling measurements were used for data analysis. The research instruments asked questions in a manner which enhanced internal validity.

Descriptive statistical analysis was used to describe the data set and gain insights and understanding of Islamic banking. For further insight, the distribution-fitting algorithmic approach was used, which changes the ordinal level scales into interval level data (Stacey, 2005). This approach is an alternative approach to analysing ordinal level response data, which involves fitting hypothesised distributions of the observed response data by calculating item means and standard deviations of the sample (Stacey, 2005).

\section{4 \\ Findings}

The majority of the respondents were men aged between 18 and 35 . In terms of education, 75 per cent of the respondents had had tertiary education; 90 per cent were employed, 36 per cent considered themselves to be very religious and 54 per cent somewhat religious. The description of the sample base is given below in Table 3:

Table 3

Demographics of respondents

\begin{tabular}{|l|l|r|}
\hline \multirow{5}{*}{ Gender } & Female: & $\%$ \\
\hline \multirow{5}{*}{ Age } & Male: & 30 \\
& $18-35$ & 70 \\
\hline \multirow{5}{*}{ Education } & $36-50$ & 70 \\
& $51-65$ & 25 \\
& $65+$ & 3 \\
\hline \multirow{5}{*}{ Employment } & Tertiary: & 2 \\
\hline & Matric: & 75 \\
& High School (incomplete): & 21 \\
& Employed & 4 \\
\hline \multirow{3}{*}{ Religious level } & Self-employed & 90 \\
& Student & 6 \\
& Retired & 2 \\
& Unemployed & 1 \\
\hline & Very religious & 36 \\
& Completely religious & 54 \\
& Somewhat religious & 2 \\
\hline
\end{tabular}


A question was posed to elicit respondents' understanding of the term Islamic banking. It was found that 58.4 per cent of respondents stated that Islamic banking pertained to interest-free banking. Of these 58.4 per cent, 23.7 per cent stated that, in addition to Islamic banking being interest-free, it was required to be Shariah-compliant. Furthermore, 24.1 per cent of respondents stated that Islamic banking pertained to Shariah compliance, but these respondents did not specifically state that Islamic banking was interest free. The other popular understanding was that Islamic banking was a way of investing in Islamic ethical investments.
The results indicate that 96.6 per cent of respondents were aware of Islamic banks. These findings bear correlation to the findings of studies conducted in countries where Islamic banking is offered. However, the findings of this study suggest that, while the level of awareness is high, the level of usage is low for transaction and finance products. In the study conducted in Singapore, the results showed that most Muslims, although aware of fundamental terms in Islam, did not understand the meaning of specific Islamic financial terms like mudaraba, musharaka and ijara (Gerrard \& Cunningham, 1997). The comparisons are given in Table 4:

Table 4

Comparison of Islamic banking awareness and usage

\begin{tabular}{|l|l|l|l|l|}
\hline \multicolumn{1}{|c|}{ Study/country } & \multicolumn{1}{|c|}{ Awareness } & \multicolumn{1}{c|}{$\begin{array}{c}\text { Usage - } \\
\text { investments }\end{array}$} & Usage - finance & $\begin{array}{c}\text { Usage - transaction } \\
\text { type products }\end{array}$ \\
\hline $\begin{array}{l}\text { This study - } \\
\text { South Africa }\end{array}$ & High: $96.6 \%$ & Low: $20 \%$ & Low: $4-8 \%$ & Low: $2-6 \%$ \\
\hline $\begin{array}{l}\text { (Naser, 1999) - } \\
\text { Jordan }\end{array}$ & High* & High: $41.7 \%$ & Low: $13.1 \%$ & High: $68.4 \%$ \\
\hline $\begin{array}{l}\text { Almossawi \& Metawa } \\
(1998) \text { - Bahrain }\end{array}$ & High* & High: $86.7 \%$ & Low:34.8\% & High: $55.6 \%$ \\
\hline $\begin{array}{l}\text { Hamid \& Nordin } \\
(1998)-\text { Malaysia }\end{array}$ & High: $96.7 \%$ & Low & Low for investments, finance and transaction type products at 39.1\% \\
\hline $\begin{array}{l}\text { (Gerrard, 1997) - } \\
\text { Singapore }\end{array}$ & Low:31\% & n/a & n/a & n/a \\
\hline
\end{tabular}

n/a: Islamic banking not yet offered in Singapore at the time of the study.

*: these studies did not state the overall level of awareness

The comparison suggests that, in countries where Islamic banking is offered, the level of awareness of Islamic banking is high (Gerrard \& Cunningham, 1997). In South Africa, Bahrain and Malaysia, Muslims are aware of Islamic banking products. Bahrain has a high rate of investment usage, while South Africa has a lower usage rate of 20 per cent for investment products. In Jordan and Malaysia, Islamic banks offer transaction-type products and are used at a higher level than that for financing products. The results suggest that the usage level varies, depending on the type of product. In a study carried out in Jordan, Naser and A-1 Khatib (1999) found that the level of awareness of Islamic banking was generally high, but that the usage level was much lower than the level of awareness.

\subsection{Factors influencing the choice of banks}

For the South African study on the use of interest-free banking products, the most commonly used of these products were savings/investments accounts and equity funds. The results indicate that only 20 per cent of the respondents used these two types of interestfree investment products.

The results indicate that the respondents used more banking products with the conventional banks. Most of the respondents had current and transactional accounts, credit cards, ATM cards and cheque accounts with non-Islamic banks. The results also indicate that few of the respondents were using telephone banking. Overall, the respondents' used minimal products from the Islamic banks. The most popular products used at these banks 
are savings and investment accounts, and equity funds or unit trusts, where 20 per cent of the respondents use them respectively. 81 per cent of the respondents use conventional banks for current or transaction accounts. Cheque books, ATM cards, credit cards and Internet banking are used mainly at the conventional banks. Usage levels are given in Table 5:

Table 5

Usage levels of Interest free banking products

\begin{tabular}{|l|l|c|c|c|}
\hline \multirow{2}{*}{ Rank } & \multicolumn{1}{|c|}{ Bank product/service } & $\begin{array}{c}\text { Interest free } \\
\text { Islamic banks } \\
\%\end{array}$ & $\begin{array}{c}\text { Interest based } \\
\text { banks } \\
\%\end{array}$ & $\begin{array}{c}\text { Do not } \\
\%\end{array}$ \\
\hline 1 & Savings/investment accounts & 20 & 42 & 38 \\
\hline 2 & Equity funds/unit trusts & 20 & 21 & 59 \\
\hline 3 & House/property finance & 8 & 32 & 59 \\
\hline 4 & Current/Transaction accounts & 6 & 81 & 13 \\
\hline 5 & Vehicle finance & 6 & 33 & 61 \\
\hline 6 & Cheque book & 5 & 66 & 29 \\
\hline 7 & ATM card & 4 & 74 & 22 \\
\hline 8 & Business/trade finance & 4 & 8 & 88 \\
\hline 9 & Credit card & 3 & 76 & 21 \\
\hline 10 & Internet banking & 4 & 65 & 32 \\
\hline 11 & Overdraft & 3 & 30 & 67 \\
\hline 12 & Telephone banking & 2 & 18 & 80 \\
\hline
\end{tabular}

Thirty-eighty percent (38\%) of the respondents had no savings or investment accounts, and 59 per cent had no equity or unit trusts. The majority of the respondents did not use business or trade finance, had no overdraft, and did not use telephone banking. In a study conducted in Malaysia on Islamic home financing, the deciding factors in order of importance were Shariah principles, lower monthly payment, transparency practice, interest-free practice and 100 per cent financing (Amin, 2008).

On the number of banks used by the respondents, 50 per cent used more than 1 bank and 50 per cent used only 1 bank. On the use of interest-free Shariah-compliant banks, 79.6 per cent of the respondents used only conventional banks, 19.6 per cent used both conventional and Islamic banks, and 0.8 per cent used an Islamic bank only. A Chi-squared test was used to test the relationship between the religious levels (assessed in the demographics section) and the use of Islamic banking as opposed to conventional banking. The Chi-square test statistic of 5.222 and a p-value of 0.4669 were non-significant, indicating that religious level is not associated with type of banking used.

Table 6

Reasons for using more than one bank

\begin{tabular}{|l|l|c|}
\hline Rank & \multicolumn{1}{|c|}{ Reasons for using more than one bank } & \multicolumn{1}{|c|}{$\begin{array}{c}\text { Percentage } \\
\text { responses }\end{array}$} \\
\hline 1 & $\begin{array}{l}\text { A conventional bank for transaction purposes and an Islamic bank for Shariah- } \\
\text { compliant savings/investment purposes }\end{array}$ & $29.6 \%$ \\
\hline 2 & $\begin{array}{l}\text { A conventional bank for transaction purposes and another conventional bank for } \\
\text { lower interest rates on finance }\end{array}$ & $16.8 \%$ \\
\hline 3 & For a better and wider range of banking options & $12 \%$ \\
\hline 4 & $\begin{array}{l}\text { A conventional bank for transaction purposes and another conventional bank for } \\
\text { savings/investment purposes }\end{array}$ & $12 \%$ \\
\hline 5 & $\begin{array}{l}\text { A conventional bank for transaction purpose and another conventional bank for } \\
\text { more or better credit-card facilities }\end{array}$ & $9.6 \%$ \\
\hline
\end{tabular}




\begin{tabular}{|l|l|c|}
\hline 6 & $\begin{array}{l}\text { A conventional bank for transaction purposes and an Islamic bank for Shariah- } \\
\text { compliant finance }\end{array}$ & $8.8 \%$ \\
\hline 7 & Convenience & $8.8 \%$ \\
\hline 8 & Other (unclassified) & $2.4 \%$ \\
\hline
\end{tabular}

The most important reason identified for using more than one bank was that conventional banks are used for transaction purposes and an interest-free bank for Shariah-compliant investment purposes (see Table 6). The results showed that 16.8 per cent used a conventional bank for transactional purposes and another conventional bank for investment purposes, 12 per cent did so in order to have a better and wider range of banking options from which to choose and select. The research indicated that 12 per cent used the Islamic banks because of the lower interest rates and 9.6 per cent did so for better or more credit-card facilities. Another 8.8 per cent did so for convenience. Respondents were asked to assume that they were planning to finance the establishment of a new business: 45 per cent stated that they would attempt to raise the finance through an equity partnership dealing with an interest-free bank. About 25 per cent would attempt to raise the finance through an equity partnership dealing with a venture capitalist or other investor, 14 per cent did not know how they would attempt to raise the finance required, 14 per cent would attempt to raise the finance by means of a loan from an interest-based bank, and 2 per cent would consider other options in an attempt to raise the finance.

In Indonesia, most Muslims use conventional banks and the cash machines because it is easier and more convenient. When it came to car financing, 65 per cent indicated that they would attempt to finance such a purchase using interest-free or Islamic banks, 19 per cent indicated that they would use the interestbased banks, 11 per cent did not know, and 5 per cent gave other reasons. For purchasing a house or property on credit, 60 per cent indicated they would use interest-free banks, 27 per cent would use interest-based loans, 10 per cent did not know, and 3 per cent would use other sources. Respondents were asked why they would use interest-free banking, and 88.4 per cent responded that they would do this for religious reasons, while 5.6 per cent would do it for a higher return on investment.

The results are given in Table 7 ,

Table 7

Importance of bank attributes

\begin{tabular}{|c|c|c|c|c|c|c|c|}
\hline Rank & Bank attribute & $\underset{\substack{5 \\
\text { Very important }}}{5}$ & $\begin{array}{c}4 \\
\text { Important } \\
\%\end{array}$ & $\begin{array}{c}3 \\
\text { Neither } \\
\text { important nor } \\
\text { un-important } \\
\%\end{array}$ & $\begin{array}{c}2 \\
\text { Un- } \\
\text { important } \\
\%\end{array}$ & $\begin{array}{c}1 \\
\text { Very un- } \\
\text { important } \\
\%\end{array}$ & $\begin{array}{c}\text { Do not } \\
\text { know } \\
\%\end{array}$ \\
\hline 1 & Fast efficient service & 86.4 & 13.6 & 0.0 & 0.0 & 0.0 & 0.0 \\
\hline 2 & Lower bank charges & 78.8 & 18.8 & 1.2 & 0.4 & 0.4 & 0.4 \\
\hline 3 & Extensive ATM network & 69.6 & 22 & 5.6 & 2.0 & 0.8 & 0.0 \\
\hline 4 & Lower admin charges & 64.4 & 22.8 & 4.8 & 3.6 & 1.6 & 2.8 \\
\hline 5 & Extensive branch network & 56.0 & 29.2 & 9.2 & 3.6 & 2.0 & 0.0 \\
\hline 6 & Internet banking & 51.6 & 24.4 & 16.0 & 6.0 & 1.6 & 0.4 \\
\hline 7 & Lower interest on overdraft & 47.2 & 20.4 & 8.8 & 6.0 & 15.2 & 2.4 \\
\hline 8 & $\begin{array}{l}\text { Higher profits on } \\
\text { investments }\end{array}$ & 44.8 & 30.8 & 10.0 & 6.0 & 5.6 & 2.8 \\
\hline 9 & $\begin{array}{l}\text { Financial planning } \\
\text { assistance }\end{array}$ & 34.4 & 39.2 & 17.6 & 4.4 & 3.6 & 0.8 \\
\hline 10 & Recommendation & 13.2 & 36.0 & 35.2 & 9.6 & 4.8 & 1.2 \\
\hline 11 & Telephone banking & $9 . .2$ & 26.8 & 34.0 & 21.6 & 7.6 & 0.8 \\
\hline 12 & Higher interest on savings & 7.2 & 8.8 & 20.0 & 22.0 & 38.4 & 3.2 \\
\hline
\end{tabular}

Source: Survey 
Using the data in Table 7, the distribution fitting algorithm approach (Stacey, 2005) was applied to analyse the consumers' choice of banks. The results are given in Table 8 below.

Table 8

Importance of bank attributes using distribution fitting algorithm approach

\begin{tabular}{|l|c|c|c|c|}
\hline \multicolumn{1}{|c|}{ Attributes } & $\begin{array}{c}\boldsymbol{\mu} \\
\text { Average } \\
\text { importance }\end{array}$ & $\begin{array}{c}\boldsymbol{\sigma} \\
\text { Degree of } \\
\text { consensus }\end{array}$ & t-value & p-value \\
\hline Lower bank charges & 0.699 & 0.725 & 15.23 & 0.0000 \\
\hline Extensive ATM network & 0.548 & 0.817 & 10.60 & 0.0000 \\
\hline Fast, efficient service & 0.360 & 0.212 & 26.84 & 0.0000 \\
\hline Extensive branch network & 0.254 & 0.807 & 4.97 & 0.0000 \\
\hline Internet banking & 0.137 & 0.854 & 2.52 & 0.0122 \\
\hline Lower interest on overdraft & 0.077 & 1.472 & 0.81 & 0.4161 \\
\hline Higher profits on investments & 0.048 & 0.913 & 0.82 & 0.4104 \\
\hline Financial planning assistance & -0.135 & 0.691 & -3.09 & 0.0023 \\
\hline Recommendation & -0.517 & 0.560 & -14.50 & 0.0000 \\
\hline Telephone banking & -0.708 & 0.587 & -19.02 & 0.0000 \\
\hline Higher interest on savings & -1.264 & 0.88 & -22.29 & 0.0000 \\
\hline
\end{tabular}

Source: Survey results

The data was further analysed using the distribution fitting algorithm methodology (Stacey, 2005). The factors were analysed and the means and t-values were determined and ranked. The factors with positive means indicated that the factors are important in the choice of banks while those with negative means were deemed to indicate that the factors were either inconclusive or not significantly important. The p-values were in line with the mean results for the rankings of factors, except for the efficient services factor, which had a low mean and high $t$ value.

The results show that lower bank charges, an extensive ATM network, lower administration and efficient services are important factors in the choice of banks. The results indicate that these factors are significantly important. This is consistent with a study conducted in Malaysia, where the most important factor for Muslims when selecting financial institutions was fast and efficient service (Haron et al., 1994). Fast, efficient service had the highest t-value, although its mean was fifth on mean ranking. Other factors, the availability of internet banking, lower interest rates on overdraft and higher profits on investments are inconclusive. On the other hand, financial planning assistance, recommendations, telephone banking and higher interest rates on savings are significantly not important.

From the results of the distribution fitting algorithm approach, the mean indicates that lower bank charges are important in the choice between an Islamic and a conventional bank, which differs from the study done in the USA, which found that fast, efficient service was the most important factor (Blackson et al., 2007). There is consensus that higher interest on savings, Internet banking, higher profits on investments and financial planning assistance are least important in the bank attributes. The results indicate that telephone banking and recommendations by friends or family are negatively related to the choice of banks. Using the $p$-value results, Internet banking, lower interest rates on overdrafts and higher profits on investment, as well financial planning factors, are not significantly important in the choice of a bank.

\subsection{Discussion}

The main characteristics of Islamic banking are Shariah-compliance and profit/loss risk sharing between borrower and lender. It was found that 96.6 per cent of the respondents knew of the four major attributes of Islamic banking. The results indicate that only about 20 per cent of the respondents used interest- 
free investments, which include savings, equity funds, unit trusts, and investments. In addition, only about 4-8 per cent of the respondents used Muslim banks to finance vehicles, house/property and business finance. Only about 2-6 per cent used transaction-type products, which are transaction accounts, chequebook facilities, debit/ATM cards, credit cards, Internet banking, overdraft facility and telephone banking. Furthermore, there is no significant relationship between a religious Muslim person and the use of Islamic banking services.

The main factors influencing the choice of banks identified in this study are fast and efficient service, lower bank charges, the availability of ATMs, lower administrative charges and an extensive branch network. In the study by Naser and A-1 Khatib (1999), the important factors in the choice of banks were shown to be convenience (location), friends' recommendations, the reputation of the bank, the availability of credit, competitive interest rates, the friendliness of the bank staff, service charges, adequate banking hours, availability of the ATM, special services and the quality of services on checque accounts (Naser \& A-1 Khatib, 1999). These important attributes vary from country to country and are dependent on the age, gender, income, marital status, occupation and cultural background of customers, as well as the type of bank, Islamic or conventional (Naser \& A-1 Khatib, 1999). Other studies indicate that factors such as the bank's reputation, business hours, parking facilities, services offered, recommendations by friends and relatives, fast and efficient service, being able to pay utility bills and financial counselling services were considered more important by male customers than by female customers in Turkey (Naser \& A-l Khatib, 1999).

In this South African study, it can be deduced that consumers' choice of a bank depends on fast and efficient service (see Table 9). The other important attributes were lower bank and administration charges, and extensive ATM and branch networks.

Table 9

Comparison of key bank selection criteria

\begin{tabular}{|l|l|l|}
\hline \multicolumn{1}{|c|}{ This study: South Africa } & $\begin{array}{l}\text { Highly-ranked attributes } \\
\text { Fast and efficient service } \\
\text { Lower bank and administration charges } \\
\text { Extensive ATM and branch networks }\end{array}$ & $\begin{array}{l}\text { Low-ranked attributes } \\
\text { Telephone banking } \\
\text { Recommendations by family, friends and } \\
\text { colleagues }\end{array}$ \\
\hline $\begin{array}{l}\text { Kennington, Hill \& } \\
\text { Rakowska (1996): Poland }\end{array}$ & $\begin{array}{l}\text { Reputation of bank } \\
\text { Low interest rates on finance } \\
\text { Superior service }\end{array}$ & Recommendations by friends and family \\
\hline $\begin{array}{l}\text { Nasser et al. (1999): } \\
\text { Jordan }\end{array}$ & $\begin{array}{l}\text { Reputation of bank } \\
\text { Confidentiality of bank }\end{array}$ & $\begin{array}{l}\text { Low service charges } \\
\text { Recommendations by friends and family }\end{array}$ \\
\hline Gerrard (1997) Singapore & $\begin{array}{l}\text { Fast and efficient service } \\
\text { Confidentiality of bank } \\
\text { Reputation of bank }\end{array}$ & $\begin{array}{l}\text { Higher interest payments on savings } \\
\text { Recommendations by friends and family }\end{array}$ \\
\hline
\end{tabular}

One in two Muslim consumers in South Africa conduct multiple banking, of which 38.4 per cent use both an Islamic and a conventional bank, while the remaining 61.6 per cent use multiple conventional banks. The reason for using both conventional and Islamic banks is that conventional banks do not offer Shariah-compliant investment and finance products. The Muslim consumers intend to invest in Islamic investments and raise finance from these banks. There is a discrepancy between the intended behaviour and awareness and actual behaviour in using Islamic banking.

The results of the study conducted in Malaysia indicated that knowledgeable and competent personnel was the most important factor in the choice of Islamic banks, followed by friendly personnel and customer service (fast and efficient services), while the price of products and proximity to home and work were the least important (Dusuki \& Abdullah, 2007). In Malaysia, Islamic bankers can no longer depend on marketing strategy attracting 
pious and religious customers (Dusuki \& Abdullah, 2007), which concurs with the results from this South African study.

\section{5}

\section{Conclusion}

The paper attempted to establish the customer awareness and use of Islamic banks in South Africa. The study fills an important gap in the literature, that of exploring the awareness of Islamic banking and the attributes customers require from the Islamic banks. Knowing the reasons why customers want to do business with certain banks and not others would save banks money, as they would be able to target their communication at the right factors and market segment (Wel \& Nor, 2003).

With a population of over 1 million South African Muslims, it was hypothesised that all Muslims would use Islamic banks, since these banks are in the country. It was found that the majority of Muslims are aware of Muslim banks but do not use them. The usage rate is very low, the main reason being that Muslim customers are looking for efficiency, ATM availability and accessibility. With this information, Islamic banks should not overemphasise and rely on the religious factor as a strategy in their effort to attract more customers (Haron et al., 1994). The study suggests that Muslim banks have to understand their potential customers and develop products that will meet their needs.

The results of this study are in line with the study done in Malaysia in 2007, which indicated that Islamic banks must not rely solely on religious factors as a strategy for securing customer allegiance, but that they should also emphasise the provision of quality and efficient products and services (Dusuki \& Abdullah, 2007).

\subsection{Limitations of the study}

The sample selection technique employed may limit generalisation of the results to the population owing to the use of non-random convenience sampling.

\subsection{Managerial implications}

Bank marketing departments should ensure that consumers have an understanding of the four main characteristics of Islamic banking, namely the Shariah-compliant, interest-free profit mark-up system, profit and loss risk sharing between the lender and the borrower and Islamic ethical projects and transactions. Potential and current customers must be educated in the principles of Islamic banking. The banks should offer fast, efficient service, as this was a highly-rated customer requirement.

\subsection{Recommendations}

With the increasing levels of competition in the banking sector, it is important for bank managers to understand the needs and expectations of the market segments served in order to attract, acquire and retain customers. The important attributes identified by this study ought to be addressed if the performance by the banks is to meet customer expectations.

\subsection{Further studies}

Further studies should be carried out to investigate how Islamic banks could provide better services to their target markets without compromising the fundamentals of Shariah law. Other studies could focus on increasing consumer awareness of the services Islamic banks offer, particularly to South Africans. A qualitative study could also be carried out to probe the motivations for using or not using Islamic banks.

\section{References}

ABRATT, R. \& RUSSELL, J. 1999. Relationship marketing in private banking in South Africa. International Journal of Bank Marketing, 17(1):5-19.

AGGRARWAL, K.R. \& YOF, T. 2000. Islamic banks and investment financing. Journal of Money, Credit and Banking, 32(1):93-120.

ALI, S.N. 1993. Information on Islamic banking and economics as represented by selected databases. International Journal of Information Management, 13:205-219. 
ALMOSSAWI, M. \& METAWA, S.A. 1988. Banking behaviour of Islamic bank customers: perspectives and implications. International Journal of Bank Marketing, 16(6/7):299-313.

ALMOSSAWI, M. 2001. Bank selection criteria employed by college students in Bahrain: An empirical analysis. International Journal of Bank Marketing, 19(3):115-125.

AL-OMAR, F. \& ABDEL-HAQ, M. 1996. Islamic banking: theory, practice and challenges $\left(1^{\mathrm{st}} \mathrm{ed}.\right)$ London: Zed Books.

AMIN, H. 2008. Choice criteria for Islamic home financing empirical investigation among Malaysian bank customers. International Journal of Housing Markets and Analysis, 1(3):256-274.

BICK, G., BROWN, B. \& ABRATT, R. 2004. Customer perceptions of the value delivered by retail banks in South Africa. The International Journal of Bank Marketing, 22(5):300-318.

BLACKSON, C., CHEN, M.S.J. \& SPEARS. 2007. Determinants of banks selection in USA, Taiwan \& Ghana. International Journal of Bank Marketing, 25(7):469-489.

BLACKWELL, D.R., MINIARD, W.P. \& ENGEL, F.J. 2006. Consumer behaviour (10 ${ }^{\text {th }}$ ed.) South-western, Mason.

BLYTHE, J. 2008. Consumer behaviour. London: Thomson Learning.

CHAPRA, M.U. 1986. Towards a just monetary system ( $1^{\text {st }}$ ed.) Leicester: The Islamic Foundation.

CHONG, B.S. \& LIU, M-H. 2008. Islamic banking: interest-free or interest-based? Pacific-Basin Finance Journal, 17:125-144.

CITI BANK 2009. Citi Islamic Investment Bank. [Online] Available at: http://www.citibank.com/ciib/ homepage/index.htm (Accessed 2009-03-29).

DEVON BANK. 2009. Islamic finance. [Online] Available at: http://www.devonbank.com/Islamic/ index.html (Accessed 2009-03-30).

DUSUKI, W.A. \& ABDULLAH, I.N. 2007. Why do Malaysian customers patronise Islamic banks? International Journal of Bank Marketing, 25(3):142-160.

EL-GAMAL, M.A. 1997. Can Islamic banking survive? A micro-evolutionary perspective. [Online] Available at: http://econpapers.repec.org/paper/attwimass/9705.htm (Accessed 2008-08-27).

EL-GAMAL, M.A. 2000. A basic guide to contemporary Islamic banking and finance. [Online] Available at: http://www.ruf.rice.edu/ elgamal (Accessed 2008-08-27).

ERIKSSON, K. 2008. The future of retail banking. International Journal of Bank Marketing, 26(1). Guest Editor.

FUNFGELD, B. \& WANG, M. 2009. Attitudes and behaviour in everyday finance: evidence from Switzerland. International Journal of Bank Marketing, 27(2):108-128.

GAINOR, T. 1999. Islamic private banking Now and in the future. AiC Worldwide Limited Conference. [Online] Available at: http://www.failaka.com/downloads/Islamic\%20Private\%20Banking\%20\%20TG\%209-1999.pdf (Accessed 2008-08-27).

GALPIN, J.D. 2000. Statistical research design and analysis. Johannesburg: Wits Press.

GHANNADIAN, F.F. \& GOSWAMI, G. 2004. Developing economy banking: the case of Islamic banks. International Journal of Social Economics, 31(8):740-752.

GERRARD, J.B. \& CUNNINGHAM. P. 1997. Islamic banking: a study in Singapore. International Journal of Bank Marketing, 15:204-216.

HAMID, A.H.A. \& NORDIN, N.A.M. 1998. A study on Islamic banking education and strategy for the new millenium-Malyasian experience. International Journal of Islamic Financial Services, 2(4).

HAR, K.Y. \& TA, H.P. 2000. A study of bank selection decisions in Singapore using the analytical hierarchy process. International Journal of Bank Marketing, 18(4):170-178.

HARON, S., AHMED, N. \& PLANISEK, S.L. 1994. Bank patronage factors of Muslim and non-Muslim customers. Internal Journal of Bank Marketing, 12(1):32-4).

HAWKINS, D.I., BEST, R.J. \& CONEY, K.A. 2004. Consumer behaviour: building marketing strategy ( $9^{\text {th }}$ ed.) New York: McGraw Hill.

History of Muslims in South Africa: a chronology. 2007. [Online] Available at: http://home.intekom.com/southafricahistoryonline/sources/history-muslims/19 (Accessed 2008-07-14). 
HOLLYWOOD, L.E., ARMSTRONG, G.A. \& DURKIN, M.G. 2007. Using behavioural and motivational thinking in food segmentation. International Journal of Retail \& Distribution Management, 35(9):691-702.

IBRAHIM, B.F.M. \& SEOWENG, O. 2006. Shariah compliance in real estate investment. [Online] Available at: http://www.rst.nus.edu.sg/research/workingpaper/2007-001.pdf. (Accessed 2009- 04-01).

KENNINGTON, C., HILL, J. \& RAKOWSKA, A. 1996. Consumer selection criteria for banks in Poland, International Journal of Bank Marketing, 14(4):12-21.

KOTLER, P. \& KELLER, L.K. 2009. Marketing management $\left(13^{\text {th }}\right.$ ed.) New Jersey: Pearson Education. MALHOTRA, K.N. \& BIRKS, F.D. 2007. Marketing research: An applied approach ( $^{\text {rd }}$ ed.) Harlow Education Limited.

MARTIN, J. 1997. Islamic banking raises interest. Management Review, 86:25-29.

MCCAWLEY, T. 2004. Islam's edicts. Far Eastern Economic Review, 167(5):36.

METAWA, M. A.S.A. 1998. Banking behaviour of Islamic bank customers: perspectives and implications. International Journal of Bank Marketing, 16:299-313.

NASER, A.L. \& A-L KHATIB, K. 1999. Islamic banking: A study of customer satisfaction and preferences in Jordan. International Journal of Bank Marketing, 17:135-150.

PATEL, E. 2006. Fundamentals of Islamic finance. Accountancy SA, $18 \pm 19$.

SAIDI, A.T. 2007. Relationships between ethical and Islamic banking systems and its business management implications. South Africa Journal of Business Management, 1:43-49.

SAUNDERS, G.S., BENDIXEN, M. \& ABRATT, R. 2007. Banking patronage motives of the urban informal pool. Journal of Services Marketing, 21(1):52-63.

SCHIFFMAN, G.L. \& KANUK, L.L. 2007. Consumer behaviour $\left(9^{\text {th }}\right.$ ed.) New Jersey: Pearson Prentice Hall.

SRIVATSA, H.S. \& SRINIVASAN, R. 2008. New age youth banking behaviour: an explorative study in the Indian banking sector. Journal of Services Research, 8(2):53-71

STACEY, G.A. 2005. The reliability and validity of the item means and standard deviations of ordinal level response data. Management Dynamics, 14(3).

TANK, J. \& TYLER, K. 2005. UK student banking revisited: influences and the decision-making process. Journal of Financial Services Marketing, 10(2):152-164.

VRONTIS, D. \& THRASSOU, A. 2007. A new conceptual framework for business-consumer relationships. Marketing Intelligence \& Planning, 25(7):789-806.

WEL, C.A.C. \& NOR, M.S. 2003. The influences of personal and sociological factors on consumer bank selection decision in Malaysia. Journal of American Academy of Business, 3(1/2):399-404. 